\title{
Forming of Innovative Resources in the Context of Ensuring Sustainable Development of Regions
}

\author{
Lubov Afanasyeva*, and Tatyana Tkacheva \\ Southwest State University, 305040 Kursk, Russia
}

\begin{abstract}
The problem of the formation of innovative resources in the context of sustainable development of the Russian Federation regions is an actual area of research, since the scientific discussion has determined that it is advisable to include innovative and institutional factors in the sustainable development triad. The key components of sustainable development, ensuring economic growth in the era of the sixth technological order are clarified and described. It has been established that modern innovative transformation in the context of sustainable development implies the introduction of IT technologies with a high degree of robotization of the production process, as well as the enhancement of information transfer procedures and the use of a large flow of information. Pursuant to the results of the study of the theory of innovative development, as well as the analysis and assessment of the Russian experience of innovation activity and the formation of innovation policy, the architecture of the strategy for the region innovative development has been substantiated. Requirements for the current modern strategy of region innovative development for sustainable development are formulated
\end{abstract}

\section{Introduction}

The problems arising as a result of the unevenness of the innovation activity of the Russian Federation constituent entities are reflected in the efficiency of the implementation of the strategies of social-and-economic regions in order to ensure the sustainable development of territories. The reasons, factors and approaches to solving this problem are analyzed and discussed by many scientists [1-4]. Thus, the author of the study [5] substantiates that the innovative development of a region is an exclusively political decision of government bodies and proposes an approach to assessing technological proximity to identify possible directions of innovative development, considering the existing structure of the regional economy. Research by A.A. Rumyantsev confirms the above provision that the degree of intensity of innovation activity is due to differences in the structure of economy sectors [6].

\footnotetext{
${ }^{*}$ Corresponding author: $\underline{1 v \_a f @ m a i l . r u}$
} 
The development and implementation of strategies for the innovative development of regions will be assessed based on the methodology for assessing the priority of the formation of centers of innovative activity [7].

One of the relevant studies in this area is the substantiation of innovative strategies focused on innovative and technological specialization of territories, the development of technology parks, technological business incubators, centers for the collective use of hightech equipment, considering the priority for the subject of the development needs of $R \& D$ [8-11].

In addition, the issues of the formation of innovative resources in the context of ensuring sustainable development of regions are relevant and insufficiently covered in the scientific literature.

\section{Research Methodology}

The Russian and foreign experience of the adopted and implemented concepts of sustainable development means association of three subsystems: economic, ecological and social [12-17]. The sustainable development triad should include innovative and institutional factors that imply the development of the digital component and the direction of the economy of impressions [18-19]. It should be noted that in the era of the sixth technological order, the key components of sustainable development that ensure economic growth are information and communication technologies facilitating the digitalization process (Figure 1).

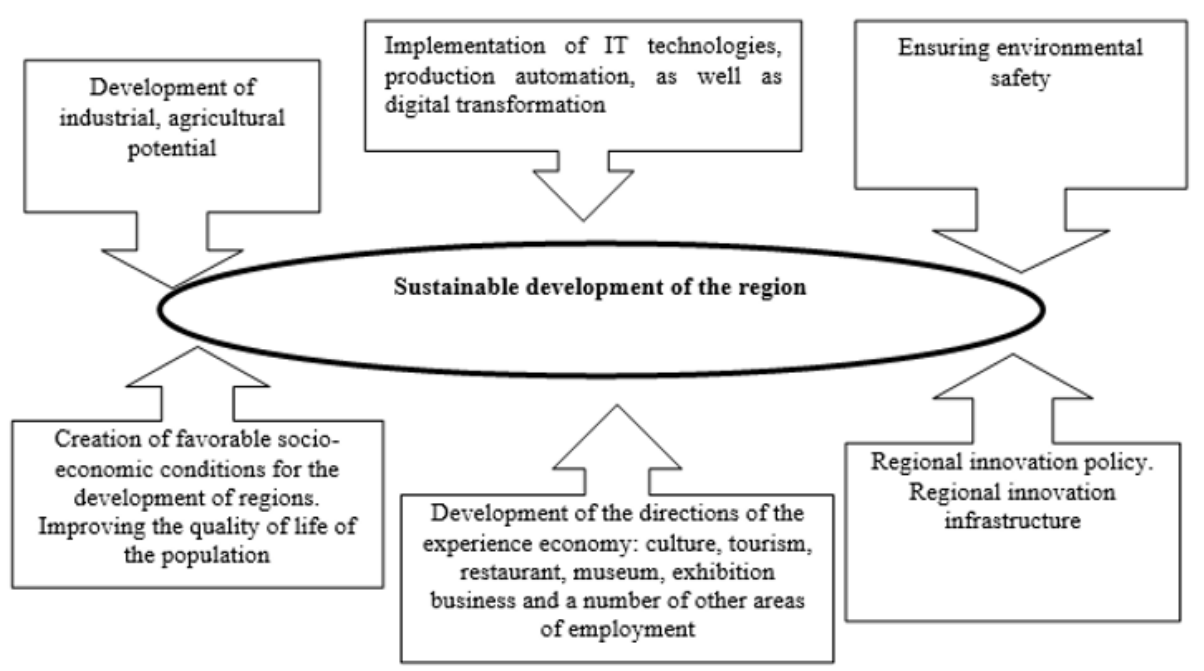

Fig. 1. Components of sustainable development of the region in modern conditions

Modern innovative transformation in the context of sustainable development implies the introduction of IT technologies with a high degree of robotization of the production process, as well as the enhancement of information transfer procedures and the use of a large flow of information that is transmitted from the consumer to the manufacturer.

The experience of developing the experience economy abroad convincingly confirms [20] that in the future the potential of the experience economy and its decisive role in the formation and development of enterprises (organizations) in the service sector will increase.

Maintaining a stable level of sustainable development of the federal center and regions implies the competitive functioning of the scientific and industrial sectors and their ability 
to transform to innovative changes under the influence of the pace of scientific, technological and digital development of society. To ensure sustainable development of the Russian Federation constituent entities, priority areas of innovative development are substantiated, considering the production and technological type of the region, the characteristics of production and the level of technological development of enterprises and organizations.

The structure of innovative resources is a collection of related resources that may provide the innovation process. Innovative resources include material and technical, financial, intellectual, personnel, organizational and managerial, information resources (figure 2).

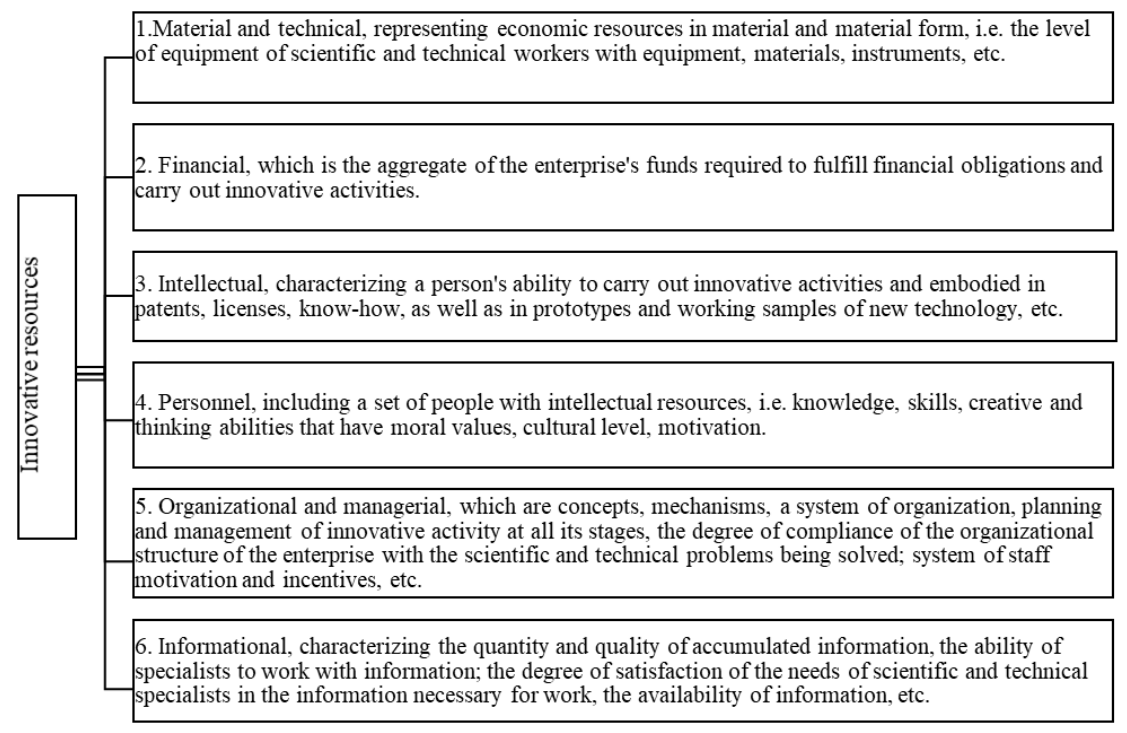

Fig. 2. Structure and content of innovative resources

Russia's transition to an innovative path of development and the formation of a national innovation system is a key factor in increasing the country's competitiveness, ensuring a high level of its economic security [21].

The problems of developing national innovation systems and improving innovation potential are a priority of economic research for all developed countries and specialized international organizations. Forecasts of long-term economic growth are based on the assessment of the efficiency of the use of accumulated human capital and the development of the country's innovation system. The experience of many countries shows that the presence of high innovation potential is a necessary factor in economic growth.

Research Methodology

Since 2007, a consortium of Cornell University (USA), INSEAD School of Business (France) and the World Intellectual Property Organization has been publishing the Global Innovation Index, formed on the basis of 80 indicators, which are combined into seven analytical areas. These analytical directions should allow to give an assessment to innovative activity.

The final rating is calculated as the average of two sub-indices - innovation resources (institutions, human capital and science, infrastructure, market and business development level) and innovation results (development of technologies and the knowledge economy, results of creative activity). 
On September 2, 2020, the "Global Innovation Index" report was presented, containing the results of a comparative analysis of the innovation systems of 131 countries and their rating by the innovative development level.

Switzerland, Sweden and the USA became the leaders in 2020. Russia took 47th place, losing one position compared to 2019.

Table 1 shows the dynamics of the positions of the Russian Federation in the Global Innovation Index.

Table 1. Dynamics of positions of the Russian Federation in the Global innovative index during 2016-2020.

\begin{tabular}{|l|c|c|c|c|c|c|c|c|c|c|}
\hline \multirow{2}{*}{ Indicator } & \multicolumn{2}{|c|}{$\mathbf{2 0 1 6}$} & \multicolumn{2}{c|}{$\mathbf{2 0 1 7}$} & \multicolumn{2}{c|}{2018} & \multicolumn{2}{c|}{$\mathbf{2 0 1 9}$} & \multicolumn{2}{c|}{$\mathbf{2 0 2 0}$} \\
\cline { 2 - 10 } & $\begin{array}{c}\text { Ran } \\
\mathbf{k}\end{array}$ & $\begin{array}{c}\text { Valu } \\
\mathbf{e}\end{array}$ & $\begin{array}{c}\text { Ran } \\
\mathbf{k}\end{array}$ & $\begin{array}{c}\text { Valu } \\
\mathbf{e}\end{array}$ & $\begin{array}{c}\text { Ran } \\
\mathbf{k}\end{array}$ & $\begin{array}{c}\text { Valu } \\
\mathbf{e}\end{array}$ & $\begin{array}{c}\text { Ran } \\
\mathbf{k}\end{array}$ & $\begin{array}{c}\text { Valu } \\
\mathbf{e}\end{array}$ & $\begin{array}{c}\text { Ran } \\
\mathbf{k}\end{array}$ & Value \\
\hline $\begin{array}{l}\text { Global } \\
\text { innovative } \\
\text { index }\end{array}$ & 43 & $\begin{array}{c}40.4 \\
7\end{array}$ & 45 & $\begin{array}{c}41.4 \\
6\end{array}$ & 46 & $\begin{array}{c}37.9 \\
0\end{array}$ & 46 & $\begin{array}{c}37.6 \\
2\end{array}$ & 47 & 35.63 \\
\hline $\begin{array}{l}\text { Innovation } \\
\text { resources }\end{array}$ & 44 & $\begin{array}{c}38.4 \\
9\end{array}$ & 43 & $\begin{array}{c}36.4 \\
8\end{array}$ & 43 & $\begin{array}{c}47.8 \\
9\end{array}$ & 41 & $\begin{array}{c}49.1 \\
1\end{array}$ & 42 & 46.64 \\
\hline $\begin{array}{l}\text { Innovatio } \\
\text { n results }\end{array}$ & 47 & $\begin{array}{c}47.5 \\
1\end{array}$ & 51 & $\begin{array}{c}48.5 \\
3\end{array}$ & 56 & $\begin{array}{c}27.9 \\
1\end{array}$ & 59 & $\begin{array}{c}26.1 \\
3\end{array}$ & 58 & 24.62 \\
\hline
\end{tabular}

Analysis of the data presented in Table 1 shows that the Russian Federation holds the highest positions in terms of the "Resources of innovation" indicator (47th place in 2016, 42 nd place in 2020). It should be noted that recently there has been a tendency towards an increase in the number of countries in the ranking, which affects a slight decrease in the position of the Russian Federation in terms of the "Global Innovation Index" and "Innovation Results".

In modern conditions, the state policy in the field of innovation has a significant impact on the scientific and technological development of the regions. The Russian experience in the implementation of innovation policy shows that the hybrid format of using the direct and indirect innovation financial regulation methods contributes to the activation of innovation processes in the region and the strengthening of its innovative potential.

Ensuring priority national interests in the innovation sphere of Russia's economic development should become a priority direction of state policy in the long term.

It should be emphasized that the allocation of the innovation component in the context of sustainable development of Russia is dictated both by the general macroeconomic state of the economy and by the state of affairs in the innovation sphere and the state regions.

Table 2 presents an analysis of the innovative activity of organizations by RF federal disctricts in 2015-2019.

Table 2. Innovative activity level of the organizations by RF federal disctricts, \%

\begin{tabular}{|c|c|c|c|c|c|c|}
\hline Territorial subordination & $\mathbf{2 0 1 5}$ & $\mathbf{2 0 1 6}$ & $\mathbf{2 0 1 7}$ & $\mathbf{2 0 1 8}$ & $\mathbf{2 0 1 9}$ & $\begin{array}{c}\text { Abs. } \\
\text { dev. } \\
\mathbf{2 0 1 9 / 2 0} \\
\mathbf{1 5}\end{array}$ \\
\hline Russian Federation & 9.3 & 8.4 & 8.5 & 12.8 & 9.1 & -0.2 \\
\hline Central Federal District & 10.9 & 10.3 & 9.9 & 16.2 & 10.8 & -0.1 \\
\hline $\begin{array}{c}\text { Northwestern Federal } \\
\text { District }\end{array}$ & 9.6 & 8.3 & 8.6 & 15.9 & 10.1 & 0.5 \\
\hline Southern Federal District & 7.6 & 7.1 & 8.4 & 9.5 & 7.5 & -0.1 \\
\hline $\begin{array}{c}\text { North Caucasian Federal } \\
\text { District }\end{array}$ & 4.7 & 2.9 & 3.2 & 4.4 & 1.7 & -3 \\
\hline Volga Federal District & 10.6 & 9.4 & 9.1 & 13.3 & 11.6 & 1 \\
\hline
\end{tabular}




\begin{tabular}{|c|c|c|c|c|c|c|}
\hline Ural Federal District & 7.9 & 8.2 & 8.2 & 14.9 & 9.3 & 1.4 \\
\hline Siberian Federal District & 8.3 & 7 & 7.6 & 9.9 & 7.5 & -0.8 \\
\hline Far Eastern Federal District & 6.9 & 6.2 & 5.9 & 8.9 & 6 & -0.9 \\
\hline
\end{tabular}

Comparative analysis of the data in Table 1 demonstrates that there have been no significant changes in the innovative activity level of organizations in federal districts. It should be noted that various climatic, social-and-economic conditions and resource components of regional innovation processes affect the innovative development level. It is important not only to assess the situation of innovative activity in federal districts, but also, to a greater extent, in the Russian Federation constituent entities.

Further, in table 3, we will analyze the total (capital and current) costs of innovative activities of organizations in the RF federal disctricts

Table 3. Total (capital and current) costs of innovative activities of organizations in RF federal disctricts, RUR mln

\begin{tabular}{|c|c|c|c|c|c|c|c|}
\hline \multirow[b]{2}{*}{$\begin{array}{c}\text { Territorial } \\
\text { subordination }\end{array}$} & \multirow[b]{2}{*}{2015} & \multirow[b]{2}{*}{2016} & \multirow[b]{2}{*}{2017} & \multirow[b]{2}{*}{2018} & \multirow[b]{2}{*}{2019} & \multicolumn{2}{|c|}{ Dynamics } \\
\hline & & & & & & $\begin{array}{c}\text { Abs. } \\
\text { dev. } \\
2019 / 20 \\
15 \\
\end{array}$ & $\begin{array}{l}\text { Gro } \\
\text { wth } \\
\text { rate }\end{array}$ \\
\hline Russian Federation & $\begin{array}{c}1,203,6 \\
38.1\end{array}$ & $\begin{array}{c}1,284,59 \\
0.3\end{array}$ & $\begin{array}{l}1,404 \\
985.3\end{array}$ & $\begin{array}{c}1,472,82 \\
2.3\end{array}$ & $\begin{array}{c}1,954,13 \\
3.3\end{array}$ & $\begin{array}{c}750,495 . \\
2\end{array}$ & 162.3 \\
\hline $\begin{array}{l}\text { Central Federal } \\
\text { District }\end{array}$ & $\begin{array}{c}411,46 \\
5.9\end{array}$ & $\begin{array}{c}528,154 . \\
7\end{array}$ & $\begin{array}{c}457,47 \\
2.1\end{array}$ & $\begin{array}{c}494,893 . \\
3\end{array}$ & $\begin{array}{c}844,271 . \\
4\end{array}$ & $\begin{array}{c}432,805 . \\
5\end{array}$ & 205.2 \\
\hline $\begin{array}{c}\text { Northwestern } \\
\text { Federal District }\end{array}$ & $\begin{array}{c}87,877 . \\
6\end{array}$ & $\begin{array}{c}115,306 . \\
5\end{array}$ & $\begin{array}{c}142,73 \\
3.8\end{array}$ & $\begin{array}{c}133,327 . \\
1\end{array}$ & $\begin{array}{c}186,847 . \\
1\end{array}$ & $98,969.5$ & 212.6 \\
\hline $\begin{array}{c}\text { Southern Federal } \\
\text { District }\end{array}$ & $\begin{array}{c}70,666 . \\
9 \\
\end{array}$ & $66,255.6$ & $\begin{array}{c}82,662 \\
.6 \\
\end{array}$ & $41,125.4$ & $79,455.8$ & $8,785.9$ & 112.4 \\
\hline $\begin{array}{l}\text { North Caucasian } \\
\text { Federal District }\end{array}$ & $5,909.1$ & $7,896.5$ & $\begin{array}{c}8,956 . \\
8\end{array}$ & $7,142.4$ & $5,189.2$ & -719.9 & 87.8 \\
\hline $\begin{array}{l}\text { Volga Federal } \\
\text { District }\end{array}$ & $\begin{array}{c}300,12 \\
4.5 \\
\end{array}$ & $\begin{array}{c}258,847 . \\
1 \\
\end{array}$ & $\begin{array}{c}336,91 \\
9.0 \\
\end{array}$ & $\begin{array}{c}397,324 . \\
0 \\
\end{array}$ & $\begin{array}{c}437,296 . \\
2 \\
\end{array}$ & $\begin{array}{c}137,171 . \\
7 \\
\end{array}$ & 145.7 \\
\hline $\begin{array}{l}\text { Ural Federal } \\
\text { District }\end{array}$ & $\begin{array}{c}120,13 \\
1.4\end{array}$ & $\begin{array}{c}153,891 . \\
2\end{array}$ & $\begin{array}{c}186,28 \\
8.7\end{array}$ & $\begin{array}{c}142,519 . \\
8\end{array}$ & $\begin{array}{c}110,966 . \\
3\end{array}$ & $-9,165.1$ & 92.4 \\
\hline $\begin{array}{c}\text { Siberian Federal } \\
\text { District }\end{array}$ & $\begin{array}{c}137,48 \\
7.7\end{array}$ & $95,265.8$ & $\begin{array}{c}128,57 \\
3.2 \\
\end{array}$ & $\begin{array}{c}169,971 . \\
1\end{array}$ & $\begin{array}{c}174,632 . \\
0\end{array}$ & $37,144.3$ & 127 \\
\hline $\begin{array}{c}\text { Far Eastern Federal } \\
\text { District }\end{array}$ & $\begin{array}{c}69,975 . \\
1\end{array}$ & $\begin{array}{c}58,973.0 \\
7\end{array}$ & $\begin{array}{c}61,379 \\
.1\end{array}$ & $86,519.2$ & $\begin{array}{c}115,475 . \\
2\end{array}$ & $45,500.1$ & 165 \\
\hline
\end{tabular}

Thus, based on the analysis of the data in Table 3, it may be concluded that the total (capital and current) costs of innovative activities of organizations in the Russian Federation have a positive trend, so in 2019 compared to 2015 this indicator increased by RUR $750,495.2 \mathrm{mln}$, i.e. by $62.3 \%$.

Table 4 shows the share of innovative goods, works, services in the total volume of goods shipped, works performed, services in the Central Federal District for 2015-2019. 
Table 4. The share of innovative goods, works, services in the total volume of goods shipped, works performed, services in the Central Federal District, \%

\begin{tabular}{|l|c|c|c|c|c|c|}
\hline $\begin{array}{c}\text { Territorial subjects of the } \\
\text { Russian Federation }\end{array}$ & $\mathbf{2 0 1 5}$ & $\mathbf{2 0 1 6}$ & $\mathbf{2 0 1 7}$ & $\mathbf{2 0 1 8}$ & $\mathbf{2 0 1 9}$ & $\begin{array}{c}\text { Abs. } \\
\text { dev. } \\
\mathbf{2 0 1 9 / 2 0 1 5}\end{array}$ \\
\hline CFD & 12.8 & 11.6 & 6.9 & 6.2 & 5.0 & -7.8 \\
\hline Belgorod region & 5.0 & 7.3 & 11.6 & 14.9 & 13.9 & 8.9 \\
\hline Bryansk region & 16.5 & 18.8 & 7.3 & 3.3 & 5.9 & -10.6 \\
\hline Vladimir region & 9.6 & 5.8 & 8.1 & 3.6 & 6.5 & -3.1 \\
\hline Voronezh region & 12.4 & 5.9 & 6.1 & 5.9 & 7.3 & -5.1 \\
\hline Ivanovo region & 1.5 & 0.2 & 0.2 & 0.6 & 4.6 & 3.1 \\
\hline Kaluga region & 3.2 & 2.7 & 2.7 & 2.7 & 1.8 & -1.4 \\
\hline Kostroma region & 1.8 & 6.7 & 9.9 & 7.5 & 3.0 & 1.2 \\
\hline Kursk region & 6.2 & 7.6 & 8.4 & 12.0 & 5.5 & -0.7 \\
\hline Lipetsk region & 12.3 & 10.5 & 9.3 & 7.7 & 7.0 & -5.3 \\
\hline Moscow region & 13.7 & 15.8 & 14.7 & 13.2 & 5.8 & -7.9 \\
\hline Oryol region & 0.9 & 0.5 & 1.1 & 1.0 & 0.5 & -0.4 \\
\hline Ryazan region & 3.5 & 6.2 & 6.8 & 5.8 & 9.7 & 6.2 \\
\hline Smolensk region & 2.7 & 1.8 & 4.4 & 2.2 & 5.2 & 2.5 \\
\hline Tambov region & 6.1 & 4.5 & 7.9 & 9.3 & 6.7 & 0.6 \\
\hline Tver region & 5.3 & 5.5 & 3.1 & 4.5 & 5.6 & 0.3 \\
\hline Tula region & 12.4 & 11.2 & 12.7 & 12.2 & 8.2 & -4.2 \\
\hline Yaroslavl region & 7.0 & 14.9 & 12.2 & 12.8 & 6.0 & -1.0 \\
\hline
\end{tabular}

Thus, the analysis of the share of innovative goods, works, services in the total volume of goods shipped, work performed, services in the Central Federal District throughout the analyzed period showed that the leaders are the Belgorod, Ivanovo, Ryazan and Smolensk regions.

\section{Results and discussion}

In recent years, legislative documents at the regional level have reflected the peculiarities and strategic priorities of the innovative development of the Russian Federation constituent entities. It should be noted that there cannot be a single conceptual model of innovative development applicable to all Russian Federation constituent entities, since the regions differ significantly in the state of financial, production, personnel, scientific, technological and educational potential. Consequently, the formation of strategic directions of innovative development for Russian regions is an urgent and differentiated issue.

The study of the theory of innovative development, as well as the analysis and assessment of the Russian experience in the development of innovation policy made it possible to substantiate the architecture of the strategy for the region innovative development, presented in Figure 3. 


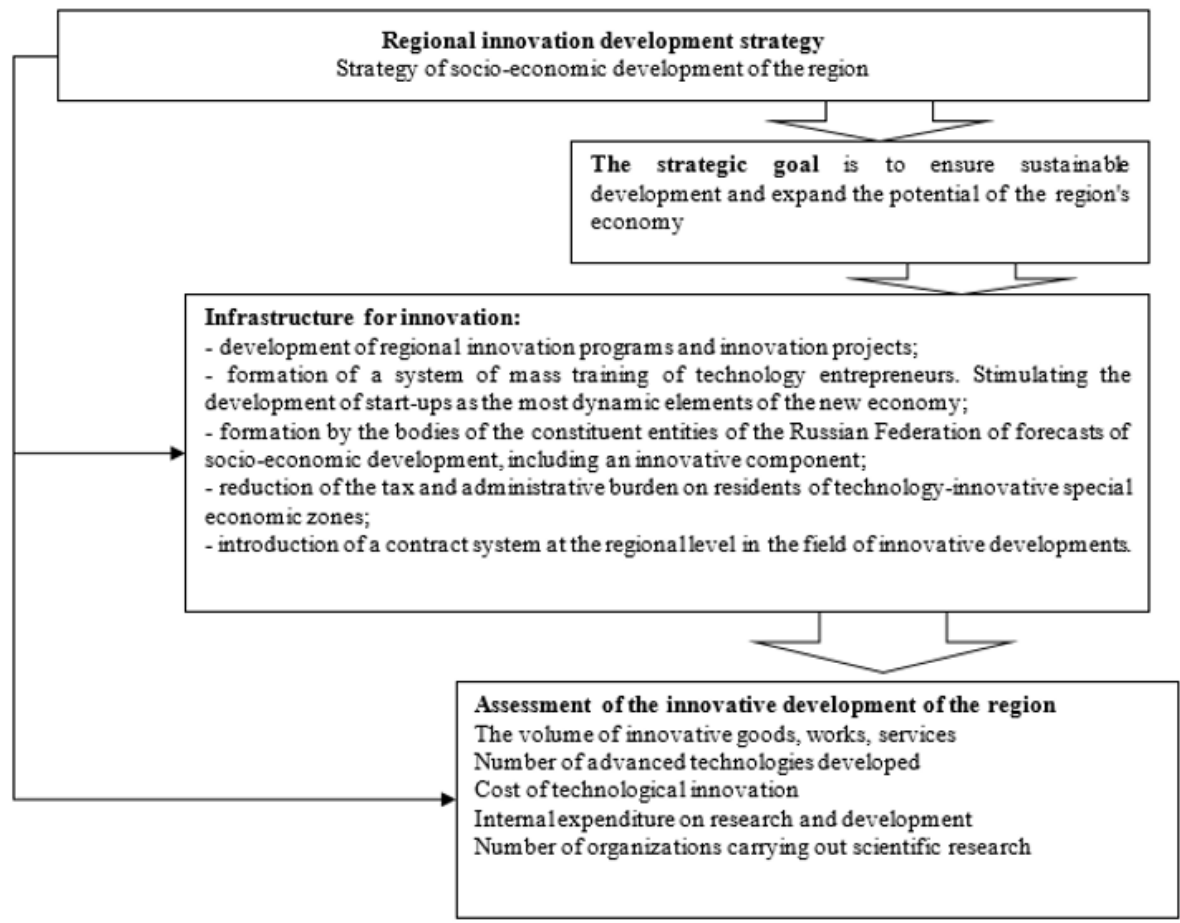

Fig.3. The architecture of the innovation development strategy

\section{Conclusions}

Analysis of foreign experience in strategic management of innovation activity shows that the architecture of the innovation development strategy is closely interconnected with the innovation development strategy of the region. Only in this case, innovation policy will be an effective tool for social-and-economic development in the long term.

Thus, a modern strategy for the region's innovative development for sustainable development should comply with the following:

- close interaction of science, business and the state in the process of formation and implementation of innovation policy;

- implementation of measures of tariff, customs and tax regulation (federal level of competence);

- orientation of science and education towards the development of a system of mass training of technological entrepreneurs;

- creation and implementation of procedures and tools in the field of public procurement, enabling government customers to purchase innovative products.

This research was conducted with the support of the Ministry of Science and Education of Russia within the framework of the project under Agreement No. 0851-2020-0034.

\section{References}

1. N.I. Komkov, Problemy prognozirovaniya, 5, 73 (2019)

2. N.A. Ganichev, O.B Koshovec, Problemy prognozirovaniya, 6, 48 (2019) 
3. Yu. Polozhentseva, M. Klevtsova, E. Leontyev, Economic Annals-XXI, 180(11-12), 78 (2019)

4. L. Belousova, S. Markina,L. Afanasjeva, I.N. Rodionova, IBIMA 2019: Education Excellence and Innovation Management through Vision 2020, 33, 2253 (2019)

5. S.N. Rastvorceva, Ekonomika regiona, 1(16), 28 (2020)

6. A.A. Rumyancev, Problemy prognozirovaniya, 1, 145 (2021)

7. I.M. Golova, A.F. Suhovej, Ekonomika regiona, 15(4), 1294 (2019)

8. D. Audretsch, R. Caiazza R, The Journal of Techology Transfer, 41(4), 1247 (2016)

9. D. Meissner, W. Polt, N.S Vonortas, The Journal of Techology Transfer, 42(5), 1184 (2017)

10. F. Landini, Journal of Evolutionary Economics, 26(2), 407 (2016)

11. S.V. Kuznecov, A.E. Miller, L.M Davidenko, Problemy prognozirovaniya, 1, 23 (2019)

12. R. Costanza, R. d'Arge, R. de Groot, St. Farber St, Nature, 387, 253 (1987)

13. Ustojchivoe razvitie: Novye vyzovy, (Aspekt Press, 2015)

14. V.A. Koptyug, Informatika. Ekologiya. Ustojchivoe razvitie, 4, 453 (2006)

15. A.D. Ursul, Vestnik MGIMO-Universiteta, 3(54), 146, (2017)

16. K.YU. Belousov, Problemy sovremennoj ekonomiki, 1(45), 45 (2013)

17. V. Rykunova, I. Kirilchuk, Ekonomichnij chasopis-XXI, 157(1-4), 103 (2016)

18. D. Kiku OON: novye gorizonty ustojchivogo razvitiya. http://russiancouncil.ru/analytics-and-comments/analytics/oon-novye-gorizontyustoychivogo-razvitiya/?sphrase_id $=342037$

19. Preobrazovanie nashego mira: Povestka dnya v oblasti ustojchivogo razvitiya na period do $2030 \quad$ goda. https://documentsddsny.un.org/doc/UNDOC/GEN/N15/285/75/PDF/N1528575.pdf?O penElement

20. O.A. Sinyugina, O.E. Akimova, Ekonomika i predprinimatel'stvo, 11, 544 (2020)

21. E.M. Korostyshevskaya, Innovacii, 6, 34 (2014)

22. Global'nyj innovacionnyj indeks, https://www.wipo.int/portal/ru/

23. Oficial'nyj sajt Federal'noj sluzhby gosudarstvennoj statistiki, https://rosstat.gov.ru 